\title{
Efektivitas Pembelajaran Online pada Masa Pandemi Covid-19 di Taman Kanak-Kanak
}

\author{
Sean Marta Efastri ${ }^{1}$, Chitra Charisma Islami ${ }^{2 凶}$ \\ Pendidikan Anak Usia Dini, Universitas Lancang Kuning Pekanbaru, Indonesia(1) \\ Pendidikan Guru Pendidikan Anak Usia Dini, Sekolah Tinggi Keguruan dan Ilmu \\ Pendidikan Muhammadiyah Kuningan, Indonesia(2) \\ DOI: $\underline{10.31004 / o b s e s i . v 6 i 2.1355}$
}

\begin{abstract}
Abstrak
Penelitian yang dilatarbelakangi dengan kondisi pembelajaran di tengah pandemi Covid-19 yang harus tetap berjalan, serta guru dituntut untuk tetap memberikan pembelajaran yang membuat siswanya mengerti dan paham sesuai dengan capaian yang diharapkan. Tujuan penelitian mengetahui efektivitas pembelajaran online yang dilakukan oleh guru PAUD di tengah pandemi Covid-19. Menggunakan metode kuantitatif deskriptif. Dengan sampel Guru PAUD Gugus Mawar Kecamatan Rumbai Pesisir yang terdiri dari 8 lembaga. Menggunakan teknik total sampling dengan jumlah responden pada penelitian ini sebanyak 30 guru dengan mengisi lembar angket (kuesioner). Teknik analisis data menggunakan teknik analisis statistik deskriptif dimana data diolah berdasarkan jawaban yang diberikan kepada responden terhadap pernyataan dari setiap angket. Hasil penelitian menunjukan bahwa efektivitas pembelajaran online selama masa pandemi Covid-19 yang dilakukan oleh guru dan anak di TK sudah efektif.
\end{abstract}

Kata Kunci: efektivitas pembelajaran online; guru paud; covid-19

\begin{abstract}
This research was conducted with the aim of knowing the effectiveness of online learning conducted by PAUD teachers in the midst of the Covid-19 pandemic. The research is motivated by learning conditions in the midst of the Covid-19 pandemic which must continue, and teachers are required to continue to provide learning that makes students understand and understand according to the expected achievements. This research was conducted using a descriptive quantitative research method. The sample in this study was the early childhood teacher Gugus Mawar Kec. Coastal Rumbai which consists of 8 PAUD institutions. The sampling technique used total sampling technique with the number of respondents in this study as many as 30 teachers. The data collection technique used in this study was a questionnaire (questionnaire). The data analysis technique in this study uses descriptive statistical analysis techniques where the data is processed based on the answers given to the respondents to the statements of each questionnaire. The conclusion of this study shows that the effectiveness of online learning during the Covid-19 pandemic carried out by teachers and children in kindergarten has been effective.
\end{abstract}

Keywords: effectiveness of online learning; paud teachers; covid-19

Copyright (c) 2021 Sean Marta Efastri, Chitra Charisma Islami

$\triangle$ Corresponding author:

Email Address : chitra@upmk.ac.id (Kuningan, Indonesia)

Received 31 February 2021, Accepted 16 June 2021, Published 18 July 2021

868 | Jurnal Obsesi : Jurnal Pendidikan Anak Usia Dini, 6(2), 2022 


\section{PENDAHULUAN}

Pada akhir tahun 2019 munculnya infeksi virus yang menyebar secara cepat, virus tersebut dinamakan Covid-19. Virus ini pertama kali ditemukan di Wuhan, China. Covid-19 menyebar secara massif di negara-negara lainnya. World Health Organization (WHO) mengumumkan pada tanggal 11 Maret 2020 bahwa Covid- 19 dinyatakan sebagai pandemi. Sampai saat ini ada 215 negara yang terjangkit virus corona (Waryanto, 2006). Indonesia adalah salah satu negara yang terjangkit Covid-19 pada Maret lalu hingga hari ini. Pandemi Covid-19 membawa pengaruh kepada semua lintas kehidupan, khusunya pendidikan. Akibat dari pandemi Covid-19 ini pelaksanaan sekolah dari taman kanak-kanak hingga universitas di tutup. UNESCO mengatakan bahwa 300 juta murid terganggu kegiatan sekolahnya dan penutupan sekolah sementara akibat dari kesehatan dan krisis (Satrianingrum \& Prasetyo, 2020). Sebagai usaha pencegahan penyebaran Covid-19, WHO merekomendasikan untuk menghentikan sementara kegiatan-kegiatan yang berpotensi menimbulkan kerumunan massa. Untuk itu pembelajaran konvensional yang mengumpulkan banyak siswa dalam satu ruangan perlu ditinjau ulang pelaksanaannya.

Ramadhani, tahun 2012, judul penelitian "Efektivitas Penggunaan Media Pembelajaran E-Learning Berbasis Web Pada Pelajaran Teknologi Informasi Dan Komunikasi Terhadap Hasil Belajar Siswa Kelas X Sma Negeri 1 Kalasan"(Ramadhani, 2012). Penelitian ini bertujuan untuk mengetahui efektivitas penggunaan media pembelajaran E-Learning berbasis web pada pelajaran Teknologi Informasi dan Komunikasi terhadap hasil belajar siswa Kelas X SMA Negeri 1 Kalasan apabila dibandingkan dengan pembelajaran konvensional. Jenis penelitian yang digunakan dalam penelitian ini adalah metode penelitian quasi eksperimen dengan sampel penelitiannya adalah kelas XA dan XB SMA Negeri 1 Kalasan. Adapun desain penelitian yang digunakan adalah pretest-posttest control group design. Uji beda dilakukan untuk mengukur perbedaan efektivitas media pembelajaran E-Learning berbasis web dan media pembelajaran konvensional berdasarkan kriteria hasil belajarnya. Hasil penelitian dapat diambil kesimpulan bahwa efektivitas media pembelajaran E-Learning berbasis web masuk dalam kriteria sedang yaitu dengan indeks normalized gain sebesar 0.54, efektivitas media pembelajaran konvensional masuk dalam kriteria sedang yaitu dengan indeks normalized gain sebesar 0.30 dan peningkatan hasil belajar dengan media pembelajaran ELearning lebih baik dibandingkan dengan peningkatan hasil belajar media pembelajaran konvensional pada materi Perangkat Lunak Pembuat Presentasi Kelas X SMA Negeri 1 Kalasan Persamaan penelitian terdahulu dengan penelitian ini sama- sama membahas efektivitas pembelajaran e-learning. Perbedaan dalam penelitian sebelumya membahas tentang hasil belajar siswa sementara dalam penelitian yang akan dilakukan membahas tentang pembelajaran online di TK Gugus Mawar Kec. Rumbai Pesisir. Nurdin, tahun 2020, dengan judul penelitian "Efektivitas Pembelajaran Online Pendidik PAUD di Tengah Pandemi Covid 19". Penelitian ini dilakukan dengan tujuan untuk mengetahui efektivitas pembelajaran online yang dilakukan oleh pendidik PAUD di tengah pandemi covid 19 di Kota Kendari. Penelitian ini dilakukan dengan metode penelitian survey deskriptif. Sampel pada penelitian ini adalah pendidik PAUD se Kota Kendari. Responden pada penelitian ini sebanyak 95 responden dan dilakukan mulai bulan Maret-Juni tahun 2020. Peneliti menggunakan teknik pengumpulan data berupa wawancara dan angket. Hasil penelitian bahwa masih ada pendidik PAUD yang tidak menjalankan pembelajaran di tengah pandemi covid 19. Masih banyak pendidik PAUD yang belum mahir menggunakan aplikasi pembelajaran online. Metode pembelajaran yang digunakan masih dominan pemberian tugas kepada peserta didik. Banyak pendidik PAUD yang tidak setuju dengan pembelajaran online karena tidak efektif dan tidak semua orang tua yang memiliki Laptop atau HP untuk pembelajaran online.

Persamaan penelitian terdahulu dengan penelitian ini teliti sama- sama membahas tentang efektivitas pembelajaran online pada masa pandemi. Perbedaan pada peneltian terdahulu dilakukan di PAUD se Kota Kediri sedangkan penelitian ini dilakukan di PAUD 
Kec. Rumbai Pesisir Satrianingrum, tahun (2020), penelitian yang berjudul "Persepsi Guru Dampak Pandemi Covid-19 terhadap Pelaksanaan Pembelajaran Daring di PAUD kota Padang". Tujuan dari penelitian ini adalah untuk memaparkan informasi terkait persepsi guru mengenai tantangan pelaksanaan pembelajaran daring di rumah akibat dampak dari pandemi Covid-19 di PAUD Kota Padang. Jenis penelitian dalam penelitian ini menggunakan studi kasus dengan pendekatan kualitatif. Hasil dari penelitian ini mengungkapkan bahwa kurang memadainya sarana dan prasarana, kurang maksimalnya penyampaian materi, beban pembelian kuota internet, koneksi internet yang kadang menjadi lamban, gaya belajar yang cenderung visual, serta kurang leluasanya guru dalam mengontrol kegiatan siswa. Perbedaan penelitian ini yaitu membahas tentang dampak pandemi Covid-19 terhadap pembelajaran online sementara penelitian ini membahas tentang efektivitas pembelajaran online di TK Gugus Mawar Kec. Rumbai Pesisir.

Pembelajaran harus dilaksanakan dengan skenario yang mampu meminimalisir kontak fisik antara siswa dengan siswa lain, ataupun antara siswa dengan guru. Berdasarkan surat edaran mengenai kebijakan sekolah saat pandemi yang diluncurkan oleh Menteri Pendidikan dan Budaya pun memberikan ketentuan, yakni proses pembelajaran dilaksanakan dari rumah untuk memberikan pembelajaran yang bermakna melalui pembelajaran daring atau jarak jauh (Mendikbud, 2020). Salah satu bentuk pembelajaran alternatif yang dapat dilaksanakan selama masa darurat Covid 19 adalah pembelajaran secara online. Pembelajaran online pada pelaksanaannya membutuhkan dukungan perangkat-perangkat mobile seperti telepon pintar, tablet dan laptop yang dapat digunakan untuk mengakses informasi dimana saja dan kapan saja. Penggunaan teknologi mobile memiliki kontribusi besar di dunia pendidikan, termasuk didalamnya adalah pencapaian tujuan pembelajaran jarak jauh. Berbagai media juga dapat digunakan untuk mendukung pelaksanaan pembelajaran secara online. Misalnya kelas-kelas virtual menggunakan layanan Google Classroom, Edmodo, dan applikasi pesan instan seperti WhatsApp. Pembelajaran secara online bahkan dapat dilakukan melalui media sosial seperti Facebook dan Instagram (Firman \& Rahayu, 2020).

Berdasarkan fenomena diatas, proses pembelajaran pada jenjang pendidikan anak usia dini haruslah tetap berlangsung, bahkan perhatian kepada mereka diberikan lebih dari kondisi normal. Anak memerlukan pendidikan untuk mengoptimalkan seluruh aspek perkembangannya demi masa depan dalam menempuh jenjang berikutnya (Kementerian Pendidikan dan Kebudayaan, 2003). Proses pembelajaran dari rumah melalui pembelajaran online idealnya tetap dapat mengakomodasi kebutuhan belajar siswa untuk mengembangkan bakat dan minat sesuai dengan jenjang pendidikannya (Yuni Sri Utami, 2021). Untuk mewujudkan hal tersebut diperlukan kesiapan pendidik, kurikulum yang sesuai, ketersediaan sumber belajar, serta dukungan peranti dan jaringan yang stabil sehingga komunikasi antar peserta didik dan pendidik dapat efektif . Kesiapan sumber daya manusia meliputi pendidik (guru dan dosen), peserta didik, dan dukungan orang tua merupakan bagian terpenting dalam pelaksanaan pembelajaran online (Cahyati \& Kusuma, 2020). Proses pembelajaran online diharapkan tetap menjadi solusi dalam masa pandemi ini. Dengan banyaknya hambatan yang dihadapi dalam proses pembelajaran online pendidik harus tetap melakukan tugasnya untuk mendidik.

Menurut Christianti, pendidik PAUD harus memiliki keahlian dalam melakukan refleksi dan menganalisis kegiatan mengajarnya. Karakteristik ini perlu dikembangkan untuk meningkatkan kemampuan guru dalam mengembangkan rencana lanjutan (Nurdin \& Anhusadar, 2020). Proses perencanaan pembelajaran juga harus tetap dilakukan sehingga indikator pencapaian perkembangan anak (Suhati1 \& Islami, 2018) tetap bisa dipertanggung jawabkan kepada orang tua. Pendidik PAUD dituntut mampu merancang dan mendesain pembelajaran online yang ringan dan efektif, dengan memanfaatkan perangkat atau mediadaring yang tepat dan sesuai dengan materi yang diajarkan kepada anak. Pendidik adalah pihak yang paling bertanggung jawab terhadap berlangsungnya pembelajaran yang efektif. Berdasarkan fenomena dilapangan terutama di TK Gugus Mawar kec. Rumbai Pesisir 
yang peneliti perolah, kondisi pembelajaran online saat ini belum dapat disebut ideal sebab masih terdapat berbagai hambatan yang dihadapi. Hambatan yang dihadapi dalam pelaksanaan pembelajaran online antara lain berkaitan dengan kesiapan sumber daya manusia, kurang jelasnya arahan pemerintah daerah, belum adanya kurikulum yang tepat, dan keterbatasan sarana dan prasarana, khususnya dukungan teknologi dan jaringan internet. Hambatan tersebut sekaligus menjadi tantangan dalam pelaksanaan pembelajaran online mengingat pelaksanaan pembelajaran online merupakan keharusan agar kegiatan pendidikan tetap dapat terselenggara di tengah darurat pandemi Covid-19 yang terjadi saat ini. Berdasarkan fenomena diatas penulis tertarik melakukan penelitian yang berjudul "Efektivitas Pembelajaran Online Pada Masa Pandemi Covid-19 Di TK Gugus Mawar Kec. Rumbai Pesisir".

\section{METODOLOGI}

Pada penelitian ini penulis memilih penelitian kuantitatif deskriptif. Metode deskriptif merupakan metode penelitian yang digunakan untuk menggambarkan masalah yang terjadi pada masa sekarang atau yang sedang berlangsung, bertujuan untuk mendeskripsikan apaapa yang terjadi sebagaimana mestinya yang terjadi pada saat penelitian dilakukan.

Tempat pelaksanaan penelitian dilakukan di TK Gugus Mawar Kecamatan Rumbai Pesisir yang dilakukan pada bulan Desember 2020. Populasi dalam penelitian ini adalah seluruh guru PAUD yang berada di Gugus Mawar Kecamatan Rumbai Pesisir. Yang terdiri dari 8 Lembaga PAUD dengan jumlah pendidik 30 orang. Teknik pengumpulan sampel dalam penelitian ini adalah total sampling Sugiyono (2014). Menurut Arikunto apabila populasi kurang dari 100 lebih baik diambil semua sehingga penelitiannya merupakan penelitian populasi, jadi sampel dalam penelitian ini 30 orang (Arikunto, 2010).

Instrumen yang digunakan dalam penelitian ini yaitu angket tertutup dan lembar observasi untuk mengamati pembelajaran online dan angket diberikan kepada guru PAUD adalah sebagai berikut: a. Uji Coba Insrumen Di dalam penelitian benar tidaknya data sangat menentukan bermutu tidaknya hasil penelitian. Sedangkan benar tidaknya data tergantung dari baik tidaknya instrumen pengumpul data. Instrumen yang baik harus memenuhi dua persyaratan penting yaitu valid dan reliabel. Tujuan diadakannya uji coba instrumen angket efektivitas pembelajaran online di TK Gugus Mawar Kec. Rumbai Pesisir adalah untuk mengetahui validitas dan reliabilitas dari instrument yang telah disusun oleh peneliti. Validitas menunjukkan derajat ketepatan antara data yang sesungguhnya terjadi pada objek dengan data yang dikumpulkan oleh peneliti. Sedangkan uji reabilitas adalah Uji reliabilitas adalah sejauh mana hasil pengukuran dengan menggunakan objek yang sama akan menghasilkan data yang sama (Sugiyono, 2008). Pengujian validitas dan reliabilitas angket ini, peneliti menggunakan perhitungan dengan menggunakan bantuan SPSS versi 23 . Keputusan pada uji validitas dan reabilitas ini yaitu apabila nilai $r$ hitung $>r$ tabel maka pernyataan tersebut dikatakan valid. Pernyataan yang telah valid kemudian bersama-sama diukur reliabilitasnya dengan melakukan hal yang sama yaitu melihat besar nilai $r$ hitung. Apabila nilai $r$ hitung > r tabel maka angket dinyatakan reliabel. b. Hasil Uji Coba Instrumen Uji coba instrumen yang dilakukan peneliti pada 10 desember 2020 kepada 30 responden dengan ketetapan nilai $\mathrm{r}$ tabel dengan nilai signifikan $5 \%$ yaitu sebesar 0.374 , adapun hasil uji validitas dan reabilitasnya.

Teknik pengumpulan data yang digunakan dalam penelitian ini adalah angket merupakan teknik pengumpulan data yang dilakukan dengan cara memberi seperangkat pertanyaan atau pernyataan tertulis kepada responden untuk dijawabnya (Sugiyono, 2014 ). Dalam hal ini angket diberikan kepada guru di TK Gugus Mawar Kec. Rumbai Pesisir untuk mengetahui efektivitas daripembelajaran online. Angket yang digunakan yaitu angket tertutup, dan diberikan kepada responden sehingga responden hanya mengisi jawaban dengan jujur dan sesuai dengan pendapatnya. Keperluan analisis data dalam penelitian ini, peneliti menggunakan metode statistik dan data yang dibutuhkan dengan skala dengan cara 
memberikan nilai pada setiap jawaban, pemberian nilai berdasarkan skala likert. Skala likert digunakan untuk mengukur sikap, pendapat, dan persepsi seseorang atau sekelompok orang tentang fenomena sosial (Sugiyono, 2008)

\section{HASIL DAN PEMBAHASAN}

Penelitian terdiri dari 1 variabel yaitu Efektivitas Pembelajaran Online di PAUD yang teridiri dari 6 indikator yaitu Pengorganisasian materi yang baik, komunikasi yang efektif, penguasaan dan antusiasisme materi pembelajaran, sikap positif terhadap anak, keluwesan dalam pembelajaran dan hasil belajar siswa baik. Penelitian dilakukan setelah pembelajaran selesai dengan menggunakan lembar angket yang telah dibuat sebelumnya. Penyebaran angket dilakukan 3 hari pada masing-masing TK, hasil dari angket dijumlah dan dirata-rata. Data yang diperoleh dideskripsikan dan dianalisis menggunakan teknik analisis data deskriptif. Masing-masing indikator Efektivitas Pembelajaran Online di PAUD diberi skor 4,3,2,1 berdasarkan deskripsi dari masing-masing indikator lalu tiap skor dikali dengan 100\% lalu dibagi dengan jumlah responden. Semua skor yang diperoleh dari rata-rata dijumlah kan semua lalu di bagi dengan jumlah pernyataan. Hasil dari presentase tersebut dianalisis berdasarkan kategori Selalu (SL), Sering (SR), Kadang-kadang (KD), Tidak Pernah (TP). Kemudian dari 6 indikator Efektivitas Pembelajaran Online di PAUD tersebut di jumlahkan untuk menghitung tingkat Efektivitas Pembelajaran Online se-Gugus Mawar secara keseluruhan. Hasil hasil tersebut dicocokkan dengan kategori rentang presentase berdasarkan pendapat dari Amelia (2015). Adapun nilai angket dan kategorinya yaitu, nilai angket $25 \%$ $43,75 \%$ masuk dalam kategori tidak efektif, nilai angket 43,75\%-62,75\% masuk dalam kategori kurang efektif, nilai angket $62,75 \%-81,25 \%$ masuk dalam kategori efektif, dan nilai angket $81,25 \%-100 \%$ masuk dalam kategori sangat efektif.

Sikap Positif Terhadap Anak dalam Pembelajaran Online, Berdasarkan hasil diatas dapat dijelaskan bahwa tingkat sikap positif terhadap anak dalam pembelajaran online pada masa pandemi Covid-19 di TK Gugus Mawar adalah 86\% dan masuk dalam kategori sangat efektif. Hasil penelitian diatas dalam sikap positif terhadap anak selama pembelajaran sudah sangat efektif dimana guru selalu memberikan nilai sesuai dengan kemampuan anak dan dalam pembelajaran online guru menampilkan beberapa vidio yang dapat memotivasi agar semangat mengikuti pembelajaran dan memberikan reward terhadap keberhasilan anak. Dimana pendapat Wahyuningsih (2016) mengatakan peran guru PAUD dalam efektivitas pembelajaran yaitu memberikan dorongan dan semangat kepada anak saat mengalami kesulitan atau kegagalan dalam sesuatu apalagi dimasa pandemi Covid-19 ini. Namun dari ketiga pernyataan angket peneliti menemukan masih ada guru yang kurang paham menggunakan media online untuk membuat beberapa vidio motivasi kepada anak Sehingga dapat disimpulkan tingkat sikap positif selama pembelajaran online masa Pandemi Covid-19 di TK Gugus Mawar Kec. Rumbai Pesisir sudah sangat efektif hal ini ditunjukan dengan nilai 86\%. Tabel 1 ini akan disajikan hasil angket dari keenam aspek Efektivitas Pembelajaran Online Pada Masa Pandemi Se-Gugus Mawar Kecamatan Rumbai Pesisir dengan masingmasing aspek di tabel 1.

Berdasarkan tabel 1, dapat dilihat bahwa skor rata-rata variabel Efektivitas Pembelajaran Online dalam pengorganisasian materi yang baik adalah $83.6 \%$ dan masuk kedalam kategori indikator sangat efektif. Adapun distribusi frekuensi sangat tinggi terdapat pada butir pernyataan nomor 3 dengan presentase $83.3 \%$. Berdasarkan tabel 2, dapat dilihat bahwa skor rata-rata variabel Efektivitas Pembelajaran Online dalam komunikasi yang efektif adalah $74 \%$ dan masuk kedalam kategori indikator efektif. Adapun distribusi frekuensi sangat tinggi terdapat pada butir pernyataan nomor 4 dengan presentase $53.3 \%$. 
Tabel 1. Rekapitulasi Angket Efektivitas Pembelajaran Online dalam Pengorganisasian Materi yang Baik

\begin{tabular}{ccccccccccc}
\hline Item & No & \multicolumn{8}{c}{ Frekuensi (F) dan Presentase (\%) } & \multicolumn{2}{c}{ Skor } \\
& & \multicolumn{2}{c}{ Selalu } & \multicolumn{2}{c}{ Sering } & \multicolumn{2}{c}{ Kadang-Kadang } & Tidak Pernah & Rata-Rata \\
& & $\mathrm{F}$ & $\%$ & $\mathrm{~F}$ & $\%$ & $\mathrm{~F}$ & $\%$ & $\mathrm{~F}$ & $\%$ & $(\%)$ \\
\hline+ & 1 & 21 & 70 & 3 & 10 & 5 & 16,7 & 1 & 3,3 & 86 \\
& 2 & 13 & 43,3 & 3 & 10 & 14 & 46,7 & 0 & 0 & 74 \\
- & 3 & 3 & 10 & 0 & 0 & 2 & 6,7 & 25 & 83,3 & 90,9 \\
\hline \multicolumn{1}{c}{ Skor rata-rata gabungan pernyataan positif dan negatif } \\
\hline
\end{tabular}

Tabel 2. Rekapitulasi Angket Efektivitas Pembelajaran Online dalam Komunikasi yang Efektif

\begin{tabular}{|c|c|c|c|c|c|c|c|c|c|c|}
\hline \multirow{3}{*}{ Item } & \multirow{3}{*}{ No } & \multicolumn{8}{|c|}{ Frekuensi (F) dan Presentase (\%) } & \multirow{3}{*}{$\begin{array}{c}\text { Skor } \\
\text { Rata- } \\
\text { Rata }(\%)\end{array}$} \\
\hline & & \multicolumn{2}{|c|}{ Selalu } & \multicolumn{2}{|c|}{ Sering } & \multicolumn{2}{|c|}{ Kadang-Kadang } & \multicolumn{2}{|c|}{ Tidak Pernah } & \\
\hline & & $\mathrm{F}$ & $\%$ & $\mathrm{~F}$ & $\%$ & $\mathrm{~F}$ & $\%$ & $\mathrm{~F}$ & $\%$ & \\
\hline \multirow[t]{2}{*}{+} & 4 & 16 & 53,3 & 6 & 20 & 2 & 6,7 & 6 & 20 & 76 \\
\hline & 5 & 14 & 46,7 & 6 & 20 & 9 & 30 & 1 & 3,3 & 77,5 \\
\hline- & 6 & 0 & 0 & 12 & 40 & 13 & 43,3 & 5 & 16,7 & 69 \\
\hline \multicolumn{10}{|c|}{ Skor rata-rata gal } & 74 \\
\hline
\end{tabular}

Pada akhir tahun 2019 munculnya infeksi virus yang menyebar secara cepat, virus tersebut dinamakan COVID-19. Sejak mewabah di China Desember lalu sampai sekarang, virus corona telah menginfeksi lebih dari 110.000 orang dengan pasien meninggal mencapai lebih dari 3.600 orang di lebih 80 negara di seluruh penjuru dunia (Owen, 2020). Virus Covid19 sudah tersebar di Indonesia pada Maret 2020 hingga artikel ini ditulis. Masuknya virus korana di Indonesia membawa dampak besar terhadap kehidupan masyarakat, mulai dari kehidupan kesehatan, ekonomi, sosial, keagamaan maupun dunia pendidikan. Dampak virus corana dalam dunia pendidikan bisa terlihat pada kebijakan pemerintah pusat hingga daerah memberikan kebijakan untuk meliburkan seluruh lembaga pendidikan dari tingkat Pendidikan Anak Usia Dini (PAUD) sampai perguruan tinggi. Penghentian aktivitas pembelajaran tatap muka dialihkan dengan pembelajaran berbasis daring (online) dengan memanfaatkan teknologi yang terhubung dengan internet. Sistem pembelajaran jarak jauh ini berlaku pada semua jenjang pendidikan termasuk pada anak usia dini.

Secara resmi pemerintah Republik Indonesia melalui Menteri Pendidikan dan Kebudayaan RI mengeluarkan Surat Edaran No 4 tahun 2020 tentang pelaksanaan kebijakan pendidikan dalam masa darurat penyebaran Corona Virus Disease (Covid-19) yang menetapkan bahwa sejak tertanda 24 maret 2020 secara resmi proses pembelajaran pada semua jenjang pendidikan, termasuk pendidikan anak usia dini melakukan proses pembelajaran dari rumah melalui sistem pembelajaran online (Kemendikbud \& Menteri Pendidikan dan Kebudayaan Republik Indonesia, 2020). Proses pembelajaran dari rumah melalui pembelajaran online idealnya tetap dapat mengakomodasi kebutuhan belajar siswa untuk mengembangkan bakat dan minat sesuai dengan jenjang pendidikannya (Hartanto, 2016). Untuk mewujudkan hal tersebut diperlukan kesiapan pendidik, kurikulum yang sesuai, ketersediaan sumber belajar, serta dukungan peranti dan jaringan yang stabil sehingga komunikasi antar peserta didik dan pendidik dapat efektif (Sadikin \& Hamidah, 2020). Efektivitas pembelajaran adalah proses pembelajaran yang dilakukan oleh guru untuk mengubah kemampuan dan persepsi siswa dari yang sulit mempelajari sesuatu menjadi mudah mempelajarinya. Keefektifan program pembelajaran tidak hanya ditinjau dari segi tingkat prestasi belajar saja, melainkan harus pula ditinjau dari segi proses dan sarana penunjang. Efektivitas pembelajaran merupakan suatu ukuran keberhasilan dari proses interaksi dalam situasi edukatif untuk mencapai tujuan pembelajaran. Dengan demikian, kegiatan belajar mengajar harus senantiasa ditingkatkan efektivitasnya demi meningkatkan mutu dari pada pendidikan itu sendiri. Seorang guru harus pandai dalam memilih metode apa yang sebaiknya digunakan agar dapat ditangkap oleh anak dari apa yang disampaikan. 
Terkait dengan pembelajaran daring yang dilakukan maka keterlibatan dan partisipasi antara anak, guru, serta orang tua dalam pembelajaran daring sangatlah penting agar pembelajaran menjadi efektif (Fauziddin et al., 2021), sedangkan berdasarkan penelitian guru harus melakukan persiapan dimulai dari rencana pembelajaran, mengkomunikasikan dengan orang tua, dan fasilitas pendukung lainnya (Ayuni et al., 2021).

Sejalan dengan pendapat (Pramana, 2020; Satrianingrum, A. P., \& Prasetyo, 2020; Pramana, 2020), guru PAUD dituntut kratif dan inovatif dalam pembelajaran online, kegiatan pembelajaran dapat menggunakan alat dan bahan yang mudah dicari di sekitar rumah anak. Namun dari ketiga pernyataan angket peneliti menemukan bahwa dalam pembelajaran online masih ada guru yang memberikan tugas kepada anak tidak tepat waktu. Sehingga dapat disimpulkan tingkat keluwesan guru dalam pembelajaran online masa Pandemi Covid-19 di TK Gugus Mawar Kecamatan Rumbai Pesisir sudah efektif hal ini ditunjukan dengan nilai $80 \%$. Berdasarkan hasil penyebaran angket diketahui bahwa hasil dari setiap kategori indikator yang mempunyai nilai tertinggi yaitu adalah indikator sikap positif terhadap anak dalam pembelajaran online yaitu $86 \%$ kemudian, di tingkat kedua yaitu pada indikator pengorganisasian materi yang baik dalam pembelajaran online dengan nilai rata-rata $83.6 \%$, kemudian pada urutan yang ketiga yaitu berada pada indikator keluwesan dalam pembelajaran dalam pembelajaran online dengan perolehan skor $80 \%$ dan dilanjutkan pada tingkat ke empat oleh indikator penguasaan dan antusiasme terhadap materi pembelajaran dengan skor 75\% lalu diurutan ke lima oleh indikator komunikasi yang efektif dengan anak selama pembelajaran online dengan perolehan nilai $74 \%$. Sedangkan pada tingkat terakhir yaitu berada pada indikator hasil belajar siswa selama pembelajaran online dengan skor $61.6 \%$.

\section{SIMPULAN}

Nilai rata-rata presentase efektivitas pembelajaran online pada masa pandemi covid19 yaitu 76.8 \% dalam kategori efektif, sehingga dapat disimpulkan bahwa efektivitas pembelajaran online sudah berjalan dengan efektif yang dilakukan oleh guru dan anak selama masa pandemi Covid-19 dalam pembelajaran pada Taman Kanak-kanak di Gugus Mawar Kec. Rumbai Pesisir.

\section{UCAPAN TERIMA KASIH}

Terima kasih peneliti haturkan kepada seluruh lembaga dan seluruh pihak yang mensupport penelitian ini.

\section{DAFTAR PUSTAKA}

Ayuni, D., Marini, T., Fauziddin, M., \& Pahrul, Y. (2021). Kesiapan Guru TK Menghadapi Pembelajaran Daring Masa Pandemi Covid-19. Jurnal Obsesi : Jurnal Pendidikan Anak Usia Dini, 5(1), 414-421. https:// doi.org/10.31004/obsesi.v5i1.579

Cahyati, N., \& Kusuma, R. (2020). Peran Orang Tua Dalam Menerapkan Pembelajaran Di Rumah Saat Pandemi Covid 19. Jurnal Golden Age, 4(01), 152-159. https:// doi.org/10.29408/jga.v4i01.2203

Fauziddin, M., Mayasari, D., \& Rizki, L. M. (2021). Effective Learning for Early Childhood during Global Pandemic. Al-Ishlah: Jurnal Pendidikan, 13(1). https:// doi.org/10.35445/alishlah.v13i1.458

Firman, F., \& Rahayu, S. (2020). Pembelajaran Online di Tengah Pandemi Covid-19. Indonesian Journal of Educational Science (IJES), 2(2), 81-89. https://doi.org/10.31605/ijes.v2i2.659

Hartanto, W. (2016). Penggunaan E-Learning Sebagai Media Pembelajaran. Jurnal Pendidikan Ekonomi: Jurnal Ilmiah Ilmu Pendidikan, Ilmu Ekonomi Dan Ilmu Sosial, 10(1). 
Kemendikbud, \& Menteri Pendidikan dan Kebudayaan Republik Indonesia. (2020). Surat Edaran Nomor 4 Tahun 2020 Tentang Pelaksanaan Kebijakan Pendidikan Dalam Masa Darurat Penyebaran Coronavirus Disease (COVID-19). Republik Indonesia. https:/ / pusdiklat.kemdikbud.go.id/ surat-edaran-mendikbud-no-4-tahun-2020tentang-pelaksanaan-kebijakan- pendidikan-dalam-masa-darurat-penyebarancorona-virus-disease-covid-1-9/

Kementerian Pendidikan dan Kebudayaan. (2003). Undang-Undang No. 20 Tahun 2003 tentang Sistem Pendidikan Nasional (Sisdiknas) dan Penjelasannya. Media Wacana Press.

Mendikbud. (2020). Surat edaran Mendikbud: Pembelajaran secara daring dan bekerja dari rumah dalam rangka pencegahan penyebaran corona virus disease (COVID-19).

Nurdin, N., \& Anhusadar, L. (2020). Efektivitas Pembelajaran Online Pendidik PAUD di Tengah Pandemi Covid 19. Jurnal Obsesi : Jurnal Pendidikan Anak Usia Dini, 5(1), 686. https://doi.org/10.31004/obsesi.v5i1.699

Owen, L. (2020). Virus corona: Bagaimana Covid-19 pengaruhi kehidupan sosial perempuan di Asia. Www.Bbc.Com/Indonesia. https://www.bbc.com/indonesia/indonesia$\underline{51717312}$

Pramana, C. (2020). Pembelajaran Pendidikan Anak Usia Dini (PAUD) Dimasa Pandemi Covid-19. Indonesian Journal of Early Childhood: Jurnal Dunia Anak Usia Dini, 2(2), 116-124.

Ramadhani, M. (2012). Efektivitas Penggunaan Media Pembelajaran E-learning Berbasis Web Pada Pelajaran Teknologi Informasi dan Komunikasi Terhadap Hasil Belajar Siswa kelas X SMA Negeri 1 Kalasan. Universitas Negeri Yogyakarta.

Sadikin, A., \& Hamidah, A. (2020). Pembelajaran Daring di Tengah Wabah Covid-19. Biodik, 6(2), 109-119. https://doi.org/10.22437/bio.v6i2.9759

Satrianingrum, A. P., \& Prasetyo, I. (2020). Persepsi Guru Dampak Pandemi Covid-19 terhadap Pelaksanaan Pembelajaran Daring di PAUD. Jurnal Obsesi: Jurnal Pendidikan Anak Usia Dini, 5(1), 633. https:/ / doi.org/10.31004/obsesi.v5i1.574

Sugiyono. (2008). Metode Penelitian Kualitatif dan Pembelajaran. Metode Penelitian Kuantitatif, Kualitatif Dan R\&D. Bandung:Alfabeta.

Suhati1, S., \& Islami, C. C. (2018). Pengaruh Peran Orangtua Melalui Kegiatan Parenting Terhadap Perkembangan Sosial Emosional Anak. Jurnal Pelita PAUD, 3(1), 58-65. http://jurnal.upmk.ac.id/index.php/pelitapaud/article/view/436

Waryanto, N. H. (2006). Online Learning Sebagai Salah Satu Inovasi Pembelajaran. In Pythagoras (Vol. 2, Issue 1, pp. 10-23). http://staff.uny.ac.id/sites/default/files/132304807/Online Learning sebagai Salah Satu Inovasi Pembelajaran.pdf

Yuni Sri Utami, C. C. I. (2021). Analisis Pola Asuh Orang Tua dalam Membentuk Kepribadian Introvert pada Anak Usia Dini. Jambura Early Childhood Education Journal, 3(1). 